\title{
Characterization of adipose-derived stem cells freshly isolated from liposuction aspirates performed with Prolipostem ${ }^{\circledast}$
}

\author{
Antonella Savoia ${ }^{1}$, Angelica Perna ${ }^{2}$, Basso Di Pasquale ${ }^{1}$, Nicoletta Onori ${ }^{3}$, Antonio De Luca ${ }^{2}$, Angela Lucariello ${ }^{2}$ \\ and Alfonso Baldi ${ }^{4^{*}}$ (D)
}

\begin{abstract}
Background: Lipofilling is a cosmetic surgical procedure that consists in the withdrawal of a small quantity of fat tissue from a suitable anatomic area and the reimplantation of this tissue in another corporeal district in the same individual, so as to obtain a filling effect. Recently, adipose-derived stem cells (ADSCs) have been isolated in the aspirates. These are pluripotent mesenchymal stem cells that are able to differentiate in mature adipose cells or other adult mesenchymal cells after paracrine or autocrine hormonal stimulations, thus favoring a longer survival of the implanted tissues.
\end{abstract}

Methods: In this article, we have defined a new method for liposuction (Prolipostem ${ }^{\circledast}$ ), where the ADSCs are recovered and mixed with the suctioned adipose tissue derived from the abdominal fat, before the reimplantation.

Results: We have demonstrated by immunocytochemistry the presence of ADSCs in the adipose tissue taken with Prolipostem ${ }^{\oplus}$ from the abdominal fat and the ability of these ADSCs to differentiate in mature adipose cells in vitro.

Conclusions: The possibility to enrich the tissue to be implanted with ADSCs would assure a longer survival of the cells implanted and a regeneration of the host tissue thanks to growth and angiogenic stimuli induced by the ADSCs.

Keywords: Adipose-derived stem cells (ADSCs), Diaminobenzidine (DAB), Dulbecco's modified Eagle's medium (DMEM), Fetal bovine serum (FBS), Phosphate-buffered saline (PBS)

\section{Background}

Lipofilling is a very popular cosmetic surgical procedure. It finds several indications both in reconstructive surgery and esthetic surgery for the body remodeling (Sinno et al. 2016; Kasem et al. 2015). The technique consists in the withdrawal of a small quantity of fat tissue from a suitable anatomic area (abdomen, sides, thighs, knees) and the reimplantation of this tissue in another corporeal district in the same individual, so as to obtain a filling effect (Joyce et al. 2015; Savoia et al. 2014; Savoia et al. 2013). Therefore, the adipose tissue is taken and reimplanted in security in the same patient setting up an autologous transplant.

\footnotetext{
* Correspondence: alfonsobaldi@tiscali.it

${ }^{4}$ Department of Environmental, Biological and Pharmaceutical Sciences and Technologies, Università degli Studi della Campania "L. Vanvitelli", Caserta, Italy

Full list of author information is available at the end of the article
}

After implantation, the adipose tissue can undergo various transformations: (a) it can be quickly degraded by the organism itself if there is not adequate hematic contribution; (b) it can be encapsulated if the plan of implantation is not correct; (c) it can be calcified (above all in the mammary gland) if the amount of tissue implanted is big (Yoshimura et al. 2006). It is therefore clear that, if the fat is injected in large quantities, not all fat cells will be in contact with vascularized tissues and they will subsequently undergo apoptosis, necrosis, and resorption.

Recently, adipose-derived stem cells (ADSCs) have been isolated in the aspirates (Sterodimas et al. 2011). These are pluripotent mesenchymal stem cells that are similar to bone marrow-derived mesenchymal stem cells (Sterodimas et al. 2011; Tiryaki et al. 2011; Park et al. 2008). Indeed, ADSCs are able to differentiate in mature adipose cells or other adult mesenchymal cells after 
paracrine or autocrine hormonal stimulations (Yang et al. 2010; Takeda et al. 2015; Wang et al. 2015; Salibian et al. 2013). This characteristic of ADSCs would allow the regeneration and, therefore, a longer survival of the implanted tissues (Ryu et al. 2013; Ellenbogen et al. 2005). Unfortunately, with the standard techniques for liposuction, the vast majority of ADSCs are lost during the procedure (Sterodimas et al. 2011). In fact, suctioned adipose tissue by means of centrifugation and vacuum pressure is divided in two portions: a fatty portion that consists of shredded adipose tissue and a fluid portion composed by the saline solution pre-injected into the site of suction, peripheral blood and cells derived from adipose tissue (Sterodimas et al. 2011; Tiryaki et al. 2011). Among these cells, there are also ADSCs, as clearly demonstrated (Sterodimas et al. 2011). The liquid portion of the suction, indeed, is generally discarded and not included in the material that is implanted.

To overcome this problem, our research group has defined a new method for liposuction (Prolipostem ${ }^{\circ}$ ), where the ADSCs are recovered and mixed with the suctioned adipose tissue before the reimplantation. The possibility to enrich the tissue to be implanted with ADSCs would assure a longer survival of the cells implanted and a regeneration of the host tissue thanks to growth and angiogenic stimuli induced by the ADSCs. Goal of this work is to demonstrate the presence of ADSCs in the adipose tissue taken with Prolipostem ${ }^{\circ}$ and the ability of these ADSCs to, eventually, differentiate in mature adipose cells in vitro.

\section{Methods}

\section{Patients}

Five female patients aged between 37 and 50 years old have participated in the study. All the procedures have been performed in anti-aging centers of PROMOITALIA (Pozzuoli, Italy). All the patients had typical aging signs and required a lipofilling. All patients were carefully informed about the procedures and all signed an informed consent.

\section{Liposuction protocol}

Local anesthesia, was done with Lidocain at $1-2 \%$, diluted Epinefrin 1/200,000 and the addition of $\mathrm{NaHCO} 3$ diluted 1/9 cc. Liposuction from the abdominal fat was performed with the Prolipostem ${ }^{\circ}$ kit. Two liposuctions for a total of $40 \mathrm{ml}$ of adipose tissue were accomplished for each patient. The kit uses a special syringe with a controlled vacuum that allows the fat aspiration without the necessity of a pneumatic pump and a distinct chamber for the collection of the adipose tissue (Promobarell ${ }^{\circ}$ ). This chamber was, then, centrifuged at $3000 \mathrm{rpm}$ for $7 \mathrm{~min}$. At the end of the centrifugation, a fatty and a fluid portion were clearly visible in the chambers (Fig. 1). The

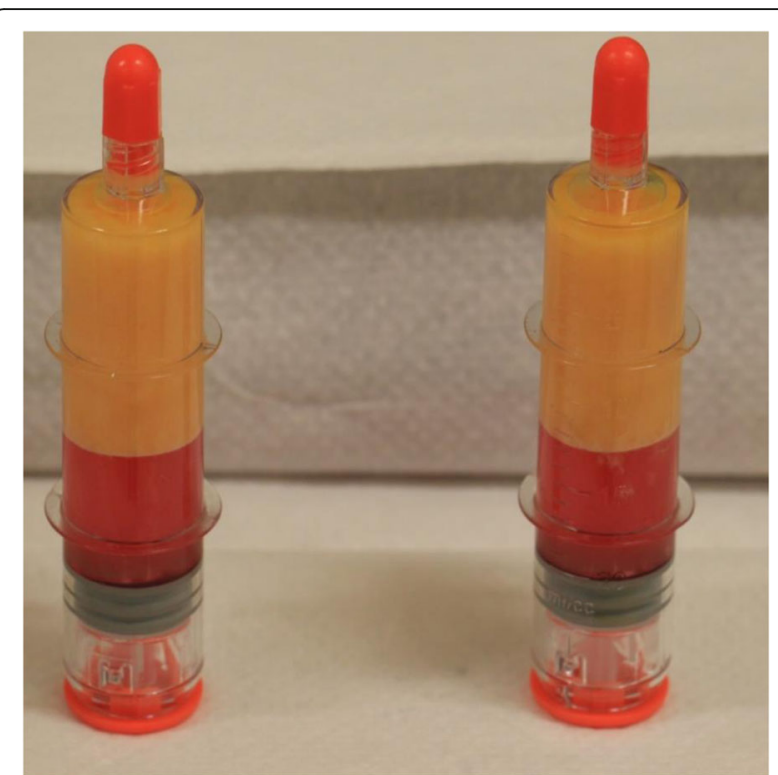

Fig. 1 Isolation of ADSCs from liposuction aspirates. At the end of the centrifugation, a fatty and a fluid portion are clearly visible in the chambers

upper portion was fatty and consisted of the suctioned adipose tissue and an oily component coming from the damaged adipose tissue; the lower portion was fluid and consisted of physiological solution mixed with anesthetics, peripheral blood, stromal tissue and ADSCs. By the use of a special nut runner, the oil component together with peripheral blood and the physiological solution were removed and the adipose tissue was mixed with the staminal cell and with the stromal component.

\section{Cell isolation}

The sample obtained from the liposuction with the Prolipostem $^{\circ}$ kit was washed with phosphate-buffered saline (PBS) containing 5\% penicillin/streptomycin in order to remove debris and the local anesthetic present after liposuction. For the tissue digestion, a $0.075 \%$ solution of collagenase I was used at a temperature of $37^{\circ} \mathrm{C}$ under stirring for $30 \mathrm{~min}$. After $30 \mathrm{~min}$, a culture medium DMEM (Dulbecco's modified Eagle's medium) containing a $10 \%$ fetal bovine serum (FBS) was added to neutralize collagenase I. After centrifuging samples at a speed of $1300 \mathrm{rpm}$ for a time of $10 \mathrm{~min}$, a pellet containing ADSCs was obtained. The pellet was resuspended with a solution containing ammonium chloride $(0.16 \mathrm{M}$ $\mathrm{NH}_{4} \mathrm{Cl}$ ) for the lysis of erythrocytes for $10 \mathrm{~min}$ and then centrifuged at a speed of $1300 \mathrm{rpm}$ for $10 \mathrm{~min}$. The pellet then was resuspended in complete culture medium (DMEM supplemented with 10\% FBS and 1\% antibiotic/antimycotic) and the cells plated at a density of $1 \times 10^{6}$ cells per dish. 


\section{Cell culture}

Freshly isolated ADSCs were plated in medium at a density of $1 \times 10^{6}$ cells per dish. Cells were cultured with standard protocol as previously described (Lucariello et al. 2015; Lucariello et al. 2013). Briefly, cells were cultured at $37{ }^{\circ} \mathrm{C}, 5 \% \mathrm{CO}_{2}$, in humid air. The culture medium was DMEM supplemented with 10\% FBS and $1 \%$ antibiotic/antimycotic. Primary cells were cultured for 7 days and were defined as "Passage 0." The medium was replaced every 3 days, and cells were passaged every week. After primary culture for 7 days, attached cells were passaged by trypsinization and plated in the same medium at a density of 2000 cells $/ \mathrm{cm}^{2}$.

\section{Induced differentiation}

Differentiation was performed with standard protocol as previously described (Manente et al. 2012; Esposito et al. 2013; Esposito et al. 2012a). Briefly, 7 days after seeding ADSCs at Passage 3-5, cell differentiation was initiated by replacing the DMEM culture medium. Cells cultured in control medium were used as negative controls. For adipogenic differentiation, confluent cultures were incubated for 14 days either in a medium without FBS and supplemented with platelets and calcium gluconate 5\%, or in a medium containing a "lipogenic solution" made up with an insulin-like peptide, glucose $5 \%$, hyaluronic acid $0.5 \%$, and calcium gluconate $1 \%$. The media were replaced every 3 days, and at 0-7-14 days of treatment, cells were stained with Oil Red $\mathrm{O}$ in order to highlight the lipid droplets.

\section{Oil Red 0}

Oil Red O was performed to visualize lipid droplets. Briefly, as previously described (Esposito et al. 2009; Esposito et al. 2012b; Esposito et al. 2015), cells were fixed with $4 \%$ paraformaldehyde for $10 \mathrm{~min}$, after they were washed with $60 \%$ isopropanol and incubated for $15 \mathrm{~min}$ to visualize lipid droplets. Cells were then washed with isopropanol and counterstained with hematoxylin. Plates were observed by a phase contrast microscope. Lipids appeared red and the nuclei appeared blue.

\section{Immunocytochemistry}

Immunocytochemistry was performed as previously described (Signorile and Baldi 2015; Spugnini et al. 2013). Briefly, fixed cells on microscope slides (4\% paraformaldehyde for $10 \mathrm{~min}$ ) were washed with PBS, then immunocytochemical analysis were made in order to confirm the presence of stem cells. For this analysis, a specific antibody for $\beta 1$-integrin (Sigma) has been used at a dilution of 1:100 for $1 \mathrm{~h}$ at room temperature. Negative controls for each tissue section were prepared by leaving out the primary antibody. After washing with triphosphate-buffered saline (TBS), sections were incubated with biotinylated goat anti-mouselanti-rabbit immunoglobulin G (Dako A $\backslash$ S, Denmark) for $10 \mathrm{~min}$, then washed with TBS, treated with streptoavidin-peroxydase reagent (Dako AlS, Denmark) for $10 \mathrm{~min}$ and washed again with TBS. Finally, cells were incubated in diaminobenzidine (DAB) for $5 \mathrm{~min}$, followed by hematoxylin counterstaining. Negative controls were performed by leaving out the primary antibody.

\section{Results \\ ADSCs are present in the adipose tissue taken with Prolipostem $^{\circledast}$}

It is well known that ADSCs express several markers (Zhu et al. 2010). To investigate the possibility that among the cells extracted from the tissue sample obtained from the liposuction with the Prolipostem ${ }^{\circ}$ procedure there were also ADSCs, we performed immunocytochemical analysis for $\beta 1$-integrin essentially as described in the "Materials and methods" section. ADSCs, once isolated from the adipose tissue, have been propagated in suitable flasks and the cultivation medium has been renewed every 2 or 3 days in order to remove the left cells in suspension. After three passages, cells were fixed and analyzed by immunohistochemistry as described in the "Materials and methods" section. Indeed, several cells were positive for integrin as shown in Fig. 2.

\section{ADSCs are able to differentiate in adult adipocytes}

ADSCs in culture, under adequate stimulus, are able to differentiate in osteoblasts, adipocytes, and chondrocytes. In this work we have induced the differentiation in adipocytes using different medium with various induction factors. Cells have been treated by 14 days, period during which they have been monitored and stained to verify any changes.

At day 0, a first Oil Red staining has been made to exclude the presence of adipocytes in the culture (Fig. 3a). At day 7, a second Oil Red staining has been made on the cells treated with the two differentiation medium. Indeed, we observed the total absence of lipid droplets in the cytoplasm of the cells treated with the first differentiation medium (Fig. 3c, d), while they were already visible in the cells treated with the second differentiation medium (Fig. 3e).

At the day 14 (end of the treatment), another Oil Red staining was performed and lipidic droplets in the cell cytoplasm were visible in all treatments (Fig. $3 g-i$ ). A negative staining with Oil Red in control cells is depicted in Fig. 3f.

\section{Discussion}

Autologous fat transplantation is an ideal treatment for facial rejuvenation and soft tissue augmentations providing "like for like" tissue material; however, the success of 

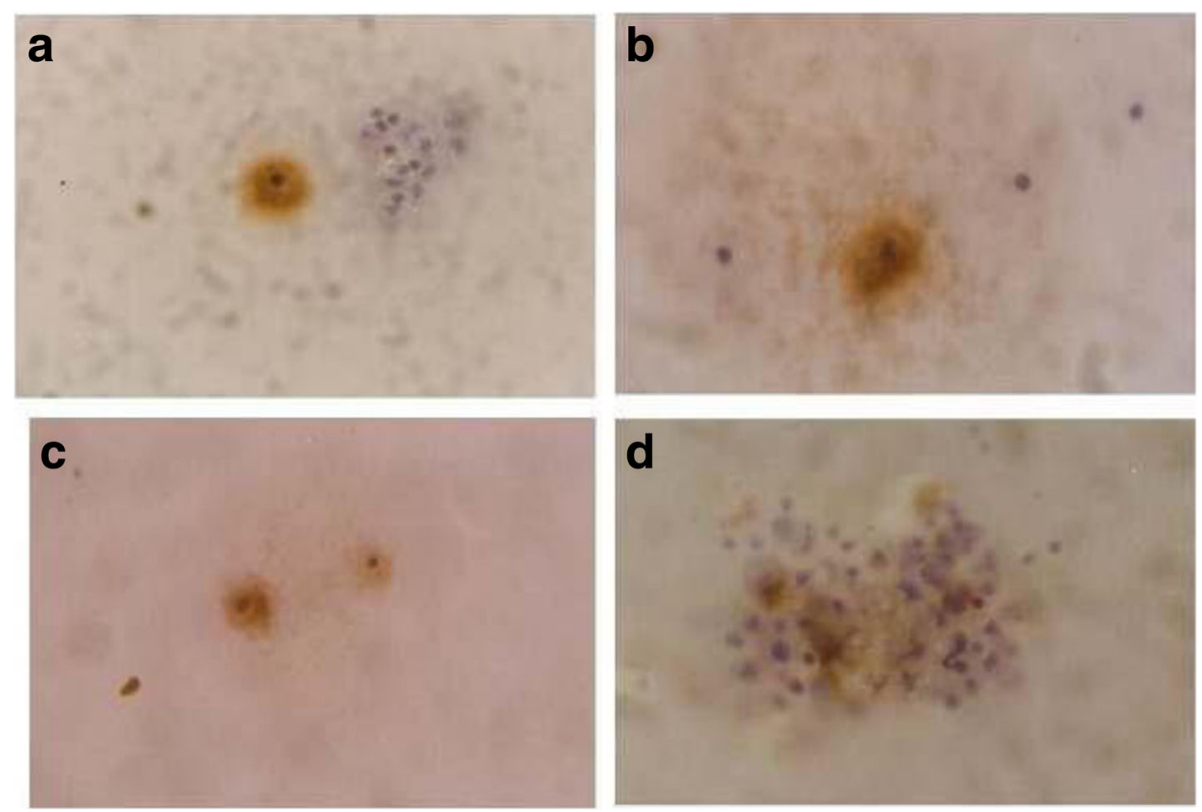

Fig. 2 Expression of $\beta 1$-integrin on the ADSCs isolated from the liposuction aspirates (a-c, original magnification $\times 40$ ). a $\beta 1$-integrin expression in an ADSC demonstrated by immunohistochemistry. $\mathbf{b} \beta 1$-integrin expression in an ADSC demonstrated by immunohistochemistry. $\mathbf{c} \beta 1$-integrin expression in two ADSCs demonstrated by immunohistochemistry. $\mathbf{d}$ A cluster of cells containing also ADSCs expressing $\beta 1$-integrin demonstrated by immunohistochemistry

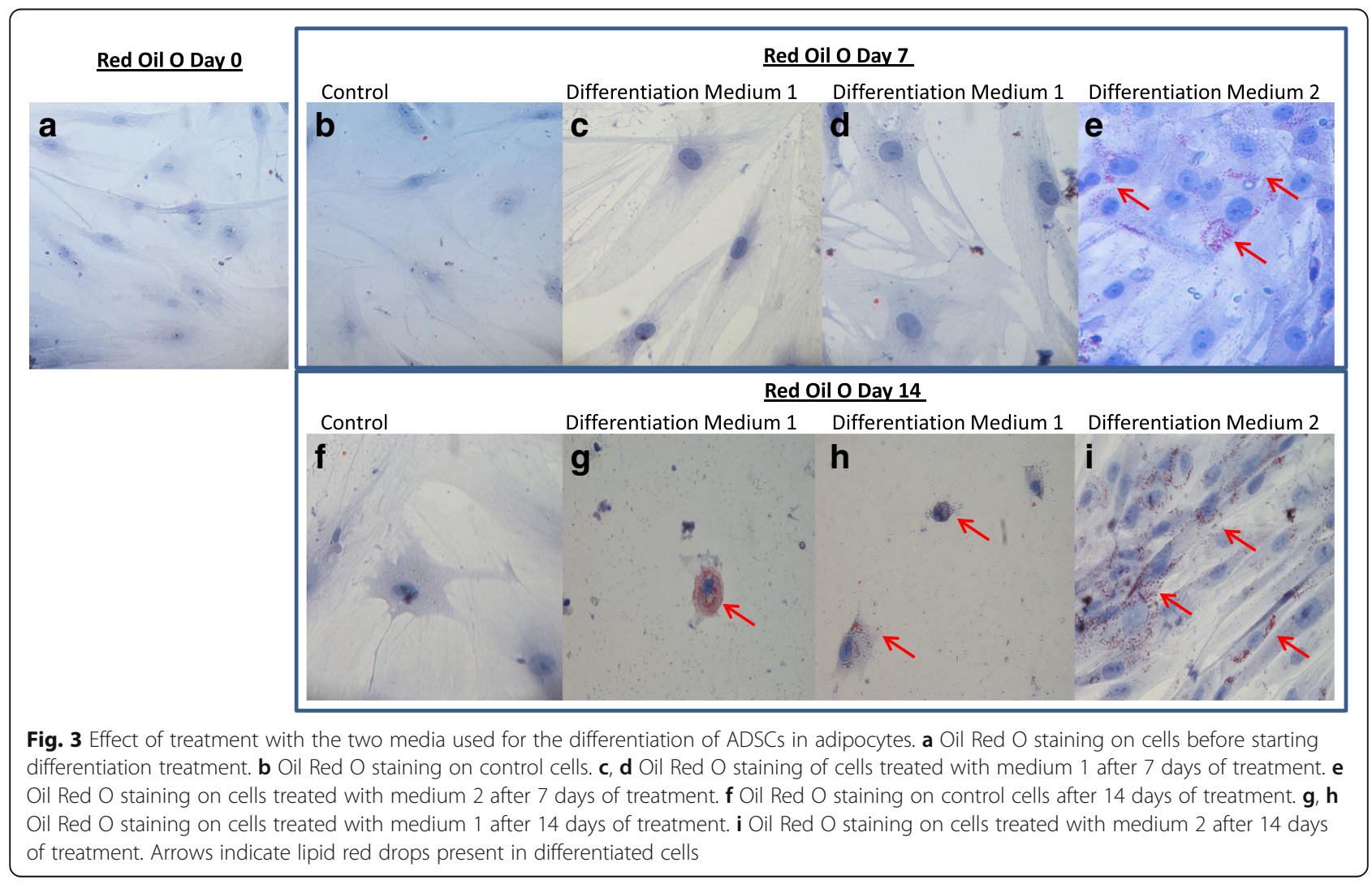


traditional fat grafting has been unpredictable and often unsatisfactory. The persistent clinical confusion associated with the viability and predictability of fat grafting is related to the mechanism of fat survival in the recipient area (Zhu et al. 2010). For large-volume fat transfers or relocations into a hostile recipient bed, the beneficiary area vascularity might be insufficient for the ischemic graft, leading to graft necrosis (Sinno et al. 2016; Kasem et al. 2015). This may be particularly true for injections into areas where the circulation and wound-healing capacity is impaired by previous fibrosis due to surgery, injections, radiotherapy, or any other acquired pathology (Kasem et al. 2015; Yoshimura et al. 2006). One recent innovation to deal with such problems is the enrichment of the transplant with autologous regenerative cells (Yoshimura et al. 2010; Yoshimura et al. 2008). For example, Yoshimura et al. (Yoshimura et al. 2008) described a cell-assisted lipo-transfer (CAL) method to graft large amounts of fat for breast augmentation and breast reconstruction.

Autologous regenerative cells can be obtained from the processing of either lipo-suctioned or excised fat (Sterodimas et al. 2011). This tissue is ease to harvest and the volume of tissue obtainable from liposuction contains 100-1000 times more pluripotent cells per cubic centimeter than bone marrow (Strem et al. 2005). According to the literature, it is possible to harvest up to $200 \times 10^{6}$ regenerative cells from 500 cc of lipo-aspirate, which makes cell culture unnecessary (Aust et al. 2004). This leads to higher safety and efficacy in clinical setting, since cells are minimally manipulated. These regenerative cells contain several types of cells, including ADSCs, vessel-forming cells, and progenitor cells, from which a variety of mesodermal cell types (bone, cartilage, blood) can be generated (Ryu et al. 2013). In detail, the ratio of adipocytes to ADSCs is constant in humans and it is independent of age and body mass index (van Harmelen et al. 2003).

Although the exact mechanism of ADSCs is unknown, it is thought that staminal cells contribute to graft survival through proangiogenic, anti-apoptotic, and proadipogenic effects (Yoshimura et al. 2010). Indeed, these cells have been shown to promote adipose cell replication, incorporate into vessel walls, and decrease the local inflammatory response (Rehman et al. 2004). Potentially, they produce a series of autocrine factors, that affect the cell itself, and paracrine, that have an effect on neighboring cells (Yang et al. 2010; Takeda et al. 2015; Wang et al. 2015). Moreover, they may contribute to neo-angiogenesis in the acute phase by secreting angiogenic factors and by acting as endothelial progenitor cells (Tiryaki et al. 2011). Thanks to their ability to differentiate into adipocytes and to induce neo-angiogenesis, when they are transplanted together with the adipose tissue, qualitatively and quantitatively improve the adipocytes increasing the possibilities for the adipose tissue to engraft (Sterodimas et al. 2011). Indeed, several clinical evidences have been published, confirming the potential role of ADSCs in either reconstructive surgery or esthetic surgery for the body remodeling (Zhu et al. 2010; Yoshimura et al. 2010; Yoshimura et al. 2008; Strem et al. 2005).

Leaving from this background, the goal of our project was to define an original and efficacious method to isolate ADSCs from liposuction aspirates. First point was the selection of the most suitable anatomical area for the liposuction. In a recent study, no statistical differences were demonstrable in adipocyte viability among thigh fat, flank fat, abdominal fat, or knee fat donor sites (Ullmann et al. 2005). Nevertheless, the abdominal area seems to be preferable for harvesting adipose tissue in which the stromal vascular fraction is well represented (Jurgens et al. 2008); therefore, in our experimental setting, the abdominal fat was chosen as an ideal source of ADSCs.

Second point was to define an experimental protocol where mechanical or chemical insults are greatly reduced to avoid damages to the tissue architecture that could cause the necrosis of the injected fat tissue (Pereira and Sterodimas 2010). Recent reports have shown that mechanical centrifugation does not appear to enhance immediate fat tissue viability before implantation (Rohrich et al. 2004). Centrifugation, however, is able to increase the concentration of the stromal vascular fraction and of ADSCs, although disproportionate centrifugation can damage adipocytes as well as ADSCs. The degree of adipocyte destruction differs among patients, but only minor differences in percentage of cell destruction have been shown among the different centrifugal forces, while a great variability is demonstrated among patients (Kurita et al. 2008). In our setting, we used centrifugation conditions comparable to that considered optimal for obtaining good results in adipose transplantation (Kim et al. 2009). To further overcome the mechanical injury of fat tissue, the Prolipostem ${ }^{\circ}$ kit was equipped with a special vacuum syringe that allows the aspiration of fat without the use of pneumatic pumps. Moreover, a special tissue fat collection chamber, defined Promobarell ${ }^{\circ}$, was designed to efficiently recover from the lower portion the stromal tissue and ADSCs at the end of the centrifugation.

The first end-point of the study was to determine the presence of ADSCs in the fatty and fluid portions of the liposuction aspirate treated with the Prolipostem ${ }^{\circ}$ kit. It is well known that ADSCs express, among the other superficial markers, $\beta 1$-integrin (Quisenberry et al. 2016; $\mathrm{Lu}$ et al. 2014). To this end, an immunocytochemical approach was used to demonstrate the expression of $\beta 1$ integrin on the surface of the ADSCs recovered. 
The second end-point of the study was to demonstrate the ability of ADSCs to differentiate in adipocytes using different mediums. Indeed, in our in vitro experimental conditions, ADSCs were able to completely differentiate into mature adipocytes, as morphologically demonstrated by Oil Red staining. The stimulation of stem cells was determined not only by biomimetic peptide but also by the other reagents, including hyaluronic acid and calcium gluconate. Interestingly, the use of platelets resulted in a more toxic effect.

Indeed, previous experiences have led to the reflection that lipogenic glucose solutions enriched with $0.5 \%$ hyaluronic acid and calcium gluconate $1 \%$ are able to induce further engraftment and differentiation of ADSCs in the host tissue (Ceccarelli and García 2010). In detail, the dermal implantation of adipose tissue is able to induce also a fibroblast differentiation of stem cells that extend and enhance the regenerative effects of the implant (Ceccarelli and García 2010). It is possible to hypothesize that the addition of lipogenic solutions to the fat tissue enriched with ADSCs in the site of implant would increase the number of mature adipocytes. This, in turn, would increase the percentage of success of the implant. This phenomenon has been named liposowing (Ceccarelli and Garcia 2011).

\section{Conclusions}

In conclusion, treatment of the abdominal fat derived from liposuction aspirates with the Proplipostem ${ }^{\bullet}$ kit is capable to isolate ADSCs that are able to differentiate in mature adipocytes in vitro thanks also to the action of lipogenetic factors that are able to amplify the phenomenon. Therefore, by combining traditional fat grafting with ADSCs, obtained by Prolipostem ${ }^{\circ}$ kit, it could be possible to overcome the problems associated with autologous fat transfer into areas with an impaired environment for fat graft survival. Additional studies are ongoing to confirm the clinical relevance of these results.

\section{Abbreviations}

ADSCs: Adipose-derived stem cell; DAB: Diaminobenzidine;

DMEM: Dulbecco's modified Eagle's medium; FBS: Fetal bovine serum;

PBS: Phosphate-buffered saline

\section{Acknowledgements \\ None}

\section{Funding}

None to acknowledge

\section{Availability of data and materials}

All data generated or analyzed during this study are included in this published article.

\section{Authors' contributions}

AS performed the liposuction with BDP; AP performed the in vitro experiments; $\mathrm{NO}$ and AL performed the immunohistochemical staining; and $A D L$ together with $A B$ and $A S$ conceived the work, analyzed the data and wrote the paper. All authors read and approved the final manuscript.

\section{Ethics approval and consent to participate}

Research involving human material has been performed in accordance with the Declaration of Helsinki of 1975, as revised in 2000 and 2008 and in accordance with the ethical code of the Università degli Studi della

Campania "L. Vanvitelli" (approved with D.R. 992/2012).

An informed consent to participate in the study has been obtained from participants.

\section{Consent for publication}

A written informed consent for the publication of data and images relating to individual participants has been obtained from the participants.

\section{Competing interests}

AS, BDP, and AB are scientific advisors of Promoitalia Group S.p.A.

\section{Publisher's Note}

Springer Nature remains neutral with regard to jurisdictional claims in published maps and institutional affiliations.

\section{Author details}

${ }^{1}$ Promoitalia Group S.p.A, Pozzuoli, Naples, Italy. ${ }^{2}$ Department of Mental and Physical Health and Preventive Medicine, Section of Human Anatomy, Università degli Studi della Campania "L. Vanvitelli", Caserta, Italy. ${ }^{3}$ San Giovanni Addolorata Hospital, Rome, Italy. ${ }^{4}$ Department of Environmental, Biological and Pharmaceutical Sciences and Technologies, Università degli Studi della Campania "L. Vanvitelli", Caserta, Italy.

Received: 22 February 2017 Accepted: 22 August 2017

Published online: 03 October 2017

\section{References}

Aust L, Devlin B, Foster SJ, Halvorsen YD, Hicok K, du Laney T, Sen A, Willingmyre GD, Gimble JM. Yield of human adipose-derived adult stem cells from liposuction aspirates. Cytotherapy. 2004;6:7-14.

Ceccarelli M, García JV. The medical face lift: face tissue regeneration. The Medical Letter Physiological. 2010;1:1-15.

Ceccarelli, M., Garcia, J.V.: Stem cell enriched fat transfer, advanced techniques in liposuction and fat transfer, Prof. NIkolay Serdev (Ed.), ISBN: 978-953-307668-3, InTech, (2011).

Ellenbogen R, Motykie G, Youn A, Svehlak S, Yamini D. Facial reshaping using less invasive methods. Aesthet Surg J. 2005;25:144-52.

Esposito M, Lucariello A, Costanzo C, Fiumarella A, Giannini A, Riccardi G, Riccio I. Differentiation of human umbilical cord-derived mesenchymal stem cells, WJ-MSCs, into chondrogenic cells in the presence of pulsed electromagnetic fields. In Vivo. 2013;27:495-500.

Esposito M, Lucariello A, Riccio I, Riccio V, Esposito V, Riccardi G. Differentiation of human osteoprogenitor cells increases after treatment with pulsed electromagnetic fields. In Vivo. 2012a;26:299-304.

Esposito V, Manente L, Lucariello A, Perna A, Viglietti R, Gargiulo M, Parrella R, Parrella G, Baldi A, De Luca A, Chirianni A. Role of FAP48 in HIV-associated lipodystrophy. J Cell Biochem. 2012b;113:3446-54.

Esposito V, Manente L, Perna A, Gargiulo M, Viglietti R, Sangiovanni V, Doula N, Liuzzi G, Baldi A, De Luca A, Chirianni A. Role of NEDD8 in HIV-associated lipodystrophy. Differentiation. 2009;77:148-53.

Esposito V, Perna A, Lucariello A, Carleo MA, Viglietti R, Sangiovanni V, Guerra G, De Luca A, Chirianni A. Different impact of antiretroviral drugs on bone differentiation in an in vitro model. J Cell Biochem. 2015;116:2188-94.

Joyce, C.W., Joyce, K.M., Rahmani, G., Walsh, S.R., Carroll, S.M., Hussey, A.J., Kelly, J. L: Fat grafting: a citation analysis of the seminal articles. Plast Reconstr Surg Glob Open 3, e295 (2015)

Jurgens WJ, Oedayrajsingh-Varma MJ, Helder MN, Zandiehdoulabi B, Schouten TE, Kuik DJ, Ritt MJ, van Milligen FJ. Effect of tissue-harvesting site on yield of stem cells derived from adipose tissue: implications for cell-based therapies. Cell Tissue Res. 2008;332:415-26.

Kasem A, Wazir U, Headon H, Mokbel K. Breast lipofilling: a review of current practice. Arch Plast Surg. 2015;42:126-30.

Kim IH, Yang JD, Lee DG, Chung HY, Cho BC. Evaluation of centrifugation technique and effect of epinephrine on fat cell viability in autologous fat injection. Aesthet Surg J. 2009;29:35-9.

Kurita M, Matsumoto D, Shigeura T, Sato K, Gonda K, Harii K, Yoshimura K. Influences of centrifugation on cells and tissues in liposuction aspirates: 
optimized centrifugation for lipotransfer and cell isolation. Plast Reconstr Surg. 2008;121:1033-41.

Lu T, Xiong H, Wang K, Wang S, Ma Y, Guan W. Isolation and characterization of adipose-derived mesenchymal stem cells (ADSCs) from cattle. Appl Biochem Biotechnol. 2014;174:719-28.

Lucariello A, Trabucco E, Boccia O, Perna A, Sellitto C, Castaldi MA, De Falco M, De Luca A, Cobellis L. Small leucine rich proteoglycans are differently distributed in normal and pathological endometrium. In Vivo. 2015;29:217-22.

Lucariello A, Trabucco E, Sellitto C, Perna A, Costanzo C, Manzo F, Laforgia V, Cobellis L, De Luca A, De Falco M. Localization and modulation of NEDD8 protein in the human placenta. In Vivo. 2013;27:501-6.

Manente L, Lucariello A, Costanzo C, Viglietti R, Parrella G, Parrella R, Gargiulo M, De Luca A, Chirianni A, Esposito V. Suppression of pre adipocyte differentiation and promotion of adipocyte death by anti-HIV drugs. In Vivo. 2012:26:287-91.

Park BS, Jang KA, Sung JH, Park JS, Kwon YH, Kim KJ, Kim WS. Adipose-derived stem cells and their secretory factors as a promising therapy for skin aging. Dermatol Surg. 2008;34:1323-6.

Pereira LH, Sterodimas A. Long-term fate of transplanted autologous fat in the face. J Plast Reconstr Aesthet Surg. 2010;63:e68-9.

Quisenberry CR, Nazempour A, Van Wie BJ, Abu-Lail NI. Evaluation of $\beta 1$-integrin expression on chondrogenically differentiating human adipose-derived stem cells using atomic force microscopy. Biointerphases. 2016;11:021005.

Rehman J, Traktuev D, Li J, Merfeld-Clauss S, Temm-Grove CJ, Bovenkerk JE, Pell CL, Johnstone BH, Considine RV, March KL. Secretion of angiogenic and antiapoptotic factors by human adipose stromal cells. Circulation. 2004;109:1292-8.

Rohrich RJ, Sorokin ES, Brown SA. In search of improved fat transfer viability: a quantitative analysis of the role of centrifugation and harvest site. Plast Reconstr Surg. 2004;113:391-5.

Ryu YJ, Cho TJ, Lee DS, Choi JY, Cho J. Phenotypic characterization and in vivo localization of human adipose-derived mesenchymal stem cells. Mol Cells. 2013;35:557-64.

Salibian AA, Widgerow AD, Abrouk M, Evans GR. Stem cells in plastic surgery: a review of current clinical and translational applications. Arch Plast Surg. 2013, 40:666-75.

Savoia A, Accardo C, Vannini F, Di Pasquale B, Baldi A. Outcomes in thread lift for facial rejuvenation: a study performed with happy lift ${ }^{\text {TM }}$ revitalizing. Dermatol Ther. 2014;4:103-14.

Savoia A, Landi S, Baldi A. A new minimally invasive mesotherapy technique for facial rejuvenation. Dermatol Ther. 2013;3:83-93.

Signorile PG, Baldi A. A tissue specific magnetic resonance contrast agent, Gd-AMH, for diagnosis of stromal endometriosis lesions: a phase I study. J Cell Physiol. 2015;230:1270-5.

Sinno S, Wilson S, Brownstone N, Levine SM. Current thoughts on fat grafting: using the evidence to determine fact or fiction. Plast Reconstr Surg. 2016;137:818-24

Spugnini EP, Di Tosto G, Salemme S, Pecchia L, Fanciulli M, Baldi A. Electrochemotherapy for the treatment of recurring aponeurotic fibromatosis in a dog. Can Vet J. 2013;54:606-9.

Sterodimas A, de Faria J, Nicaretta B, Boriani F. Autologous fat transplantation versus adipose-derived stem cell-enriched lipografts: a study. Aesthet Surg J. 2011;31:682-93.

Strem BM, Hicok KC, Zhu M, Wulur I, Alfonso Z, Schreiber RE, Fraser JK, Hedrick MH. Multipotential differentiation of adipose tissue-derived stem cells. Keio J Med. 2005:54:132-41.

Takeda K, Sowa Y, Nishino K, Itoh K, Fushiki S. Adipose-derived stem cells promote proliferation, migration, and tube formation of lymphatic endothelial cells in vitro by secreting lymphangiogenic factors. Ann Plast Surg. 2015;74:728-36.

Tiryaki T, Findikli N, Tiryaki D. Staged stem cell-enriched tissue (SET) injections for soft tissue augmentation in hostile recipient areas: a preliminary report. Aesthet Plast Surg. 2011;35:965-71.

Ullmann Y, Shoshani O, Fodor A, Ramon Y, Carmi N, Eldor L, Gilhar A. Searching for the favorable donor site for fat injection: in vivo study using the nude mice model. Dermatol Surg. 2005;31:1304-7.

van Harmelen V, Skurk T, Röhrig K, Lee YM, Halbleib M, Aprath-Husmann I, Hauner $\mathrm{H}$. Effect of BMI and age on adipose tissue cellularity and differentiation capacity in women. Int J Obes Relat Metab Disord. 2003;27:889-95.

Wang T, Guo S, Liu X, Xu N, Zhang S. Protective effects of adipose-derived stem cells secretome on human dermal fibroblasts from ageing damages. Int J Clin Exp Pathol. 2015;8:15739-48.
Yang JA, Chung HM, Won CH, Sung JH. Potential application of adipose-derived stem cells and their secretory factor to skin: discussion from both clinical and industrial viewpoints. Expert Opin Biol Ther. 2010;10:495-503.

Yoshimura A, Aoi N, Kurita M, Oshima Y, Sato K, Inoue K, Suga H, Eto H, Kato H, Harii K. Progenitor-enriched adipose tissue transplantation as rescue for breast implant complications. Breast J. 2010;16:169-75.

Yoshimura K, Sato K, Aoi N, Kurita M, Hirohi T, Harii K. Cell-assisted lipotransfer for cosmetic breast augmentation: supportive use of adipose-derived stem/ stromal cells. Aesthet Plast Surg. 2008;32:48-55.

Yoshimura K, Shigeura T, Matsumoto D, Sato T, Takaki Y, Aiba-Kojima E, Sato K, Inoue K, Nagase T, Koshima I, Gonda K. Characterization of freshly isolated and cultured cells derived from the fatty and fluid portions of liposuction aspirates. J Cell Physiol. 2006;208:64-76.

Zhu M, Zhou Z, Chen Y, Schreiber R, Ransom JT, Fraser JK, Hedrick MH, Pinkernell K, Kuo HC. Supplementation of fat grafts with adipose-derived regenerative cells (ADRCs) improves long-term graft retention. Ann Plast Surg. 2010;64:222-8.

\section{Submit your next manuscript to BioMed Central and we will help you at every step:}

- We accept pre-submission inquiries

- Our selector tool helps you to find the most relevant journal

- We provide round the clock customer support

- Convenient online submission

- Thorough peer review

- Inclusion in PubMed and all major indexing services

- Maximum visibility for your research

Submit your manuscript at www.biomedcentral.com/submit
( Biomed Central 